\title{
In Vitro and In Vivo Inhibitory Effects of Gaseous Chlorine Dioxide Against Diaporthe batatas Isolated from Stored Sweetpotato
}

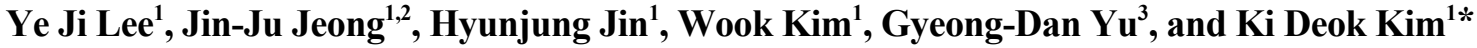 \\ ${ }^{1}$ Department of Biosystems and Biotechnology, Korea University, Seoul 02841, Korea \\ ${ }^{2}$ Institute of Life Science and Natural Resources, Korea University, Seoul 02841, Korea \\ ${ }^{3}$ Bioenergy Crop Research Institute, National Institute of Crop Science, Rural Development Administration, Muan \\ 58521, Korea
}

(Received on September 11, 2018; Revised on November 22, 2018; Accepted on December 11, 2018)

Chlorine dioxide $\left(\mathrm{ClO}_{2}\right)$ can be used as an alternative disinfectant for controlling fungal contamination during postharvest storage. In this study, we tested the in vitro and in vivo inhibitory effects of gaseous $\mathrm{ClO}_{2}$ against Diaporthe batatas SP-d1, the causal agent of sweetpotato dry rot. In in vitro tests, spore suspensions of SP-d1 spread on acidified potato dextrose agar were treated with various $\mathrm{ClO}_{2}$ concentrations $(1-20 \mathrm{ppm})$ for 0-60 min. Fungal growth was significantly inhibited at $1 \mathrm{ppm}$ of $\mathrm{ClO}_{2}$ treatment for $30 \mathrm{~min}$, and completely inhibited at $20 \mathrm{ppm}$. In in vivo tests, spore suspensions were drop-inoculated onto sweetpotato slices, followed by $\mathrm{ClO}_{2}$ treatment with different concentrations and durations. Lesion diameters were not significantly different between the tested $\mathrm{ClO}_{2}$ concentrations; however, lesion diameters significantly decreased upon increasing the exposure time. Similarly, fungal populations decreased at the tested $\mathrm{ClO}_{2}$ concentrations over time. However, the sliced tissue itself hardened after 60-min $\mathrm{ClO}_{2}$ treatments, especially at $20 \mathrm{ppm}$ of $\mathrm{ClO}_{2}$. When sweetpotato roots were dip-inoculated in spore suspensions for $10 \mathrm{~min}$ prior to treatment with 20 and $40 \mathrm{ppm}$ of $\mathrm{ClO}_{2}$ for 0-60 min, fungal populations decreased with increasing $\mathrm{ClO}_{2}$ concentrations. Taken together, these results showed that gaseous $\mathrm{ClO}_{2}$ could significantly

\footnotetext{
*Corresponding author.

Phone) +82-2-3290-3065, FAX) +82-2-925-1970

E-mail) kidkim@korea.ac.kr

(c) This is an Open Access article distributed under the terms of the Creative Commons Attribution Non-Commercial License (http:// creativecommons.org/licenses/by-nc/4.0) which permits unrestricted noncommercial use, distribution, and reproduction in any medium, provided the original work is properly cited.
}

Articles can be freely viewed online at www.ppjonline.org. inhibit $D$. batatas growth and dry rot development in sweetpotato. Overall, gaseous $\mathrm{ClO}_{2}$ could be used to control this fungal disease during the postharvest storage of sweetpotato.

Keywords : chlorine dioxide, Diaporthe batatas, dry rot, sweetpotato

Handling Editor : Lee, Yong Hoon

Sweetpotato (Ipomoea batatas Lam.) is one of the most important food crops worldwide, especially in developing countries. The crop currently ranks seventh among staple food crops after rice, wheat, potatoes, maize, barley, and cassava. (Sanusi et al., 2016). The world production of sweetpotato was estimated at $105,190 \mathrm{Mt}$, in which $74.7 \%$ was produced in China and other Asian countries, according to the Food and Agriculture Organization of the United Nations in 2016 (http://www.fao.org/faostat/en/\#data/QC/). Recently, the consumption of sweetpotato as a healthy food has been increasing; however, postharvest diseases of the crop are among the significant limitations for its production (estimated loss, 15-65\%), in terms of both quantity and quality (Ray and Ravi, 2005). Fungal contamination is one of the most serious problems during sweetpotato storage (Ray and Ravi, 2005; Scruggs and Quesada-Ocampo, 2016). Recently, Chakraborty et al. (2017) reported that Botryodiplodia theobromae, Certocystis fimbriata, Fusarium spp., and Rhizopus oryzae are the most significant fungi to sweetpotato storage contamination. These fungal pathogens cause local discoloration and disruption of surrounding tissues in infected sweetpotato, resulting in changes involving deterioration of texture and flavor (Amienyo and Ataga, 2007). Because sweetpotato stored in enclosed 
spaces, fungal contamination may spread throughout the storage facility, resulting in significantly contaminated sweetpotato (Wu and Rioux, 2010). Therefore, it is important to apply appropriate measures to limit fungal infection of sweetpotato during storage as described in other crops (Mannaa and Kim, 2018). Fungicides, such as thiabendazole, benomyl, and iprodione, are generally used to control fungal contamination in sweetpotato (Afek et al., 1998; Singh and Sharma, 2018). However, postharvest application of fungicides is generally avoided because sweetpotato roots are directly used as a food source.

Chlorine has long been used as an effective chemical to control postharvest diseases of fruits and vegetables (Zoffoli et al., 1999). This chemical can react with many organic nitrogen compounds, unsaturated organic compounds, and phenols. Thus, microorganisms can be destroyed through the oxidative action of chlorine on cellular constituents, and in part via direct combinations of the compound with membrane proteins and enzymes (Tweddell et al., 2003). In this regard, chlorine dioxide $\left(\mathrm{ClO}_{2}\right)$ gas has been shown to effectively reduce food-borne pathogens in many storage crops such as apples, green peppers, lettuce, tomatoes, cabbage, carrots, and peaches, as well as blueberries, raspberries, and strawberries (Du et al., 2002; Han et al., 2001, 2004; Lee et al., 2004; Sy et al., 2005a, 2005b). Thus, $\mathrm{ClO}_{2}$ gas can be used as an alternative disinfectant to control fungal contamination. Moreover, $\mathrm{ClO}_{2}$ gas has low toxicity in humans, reacts rapidly, and is effective at low concentrations (Vaid et al., 2010; Wang et al., 2016). $\mathrm{ClO}_{2}$ gas has been approved for use as a sanitizer for agricultural, industrial, commercial, and medical uses by the U.S. Environmental Protection Agency (2006). Although both aqueous and gaseous $\mathrm{ClO}_{2}$ are effective as sanitizing agents, gaseous $\mathrm{ClO}_{2}$ is more effective than aqueous $\mathrm{ClO}_{2}$ because the gaseous form can penetrate small spaces that the liquid form cannot reach (Han et al., 2001; Lee et al., 2004).

Recently, sweetpotato dry rot caused by $D$. batatas in Korea was reported by Lee et al. (2016). This was the first report of the disease on sweetpotato in the world besides in the USA, where it was first described (Harter and Field, 1912). The disease may, therefore, cause significant reduction in sweetpotato production worldwide, including in Korea. Although $\mathrm{ClO}_{2}$ gas may inhibit the activity of various deleterious storage fungi, $D$. batatas as an emerging fungal pathogen of sweetpotato was examined in this study. Thus, the objectives of this study were to evaluate the in vitro and in vivo inhibitory effects of various concentrations and treatment times of gaseous $\mathrm{ClO}_{2}$ against growth of $D$. batatas and dry rot development in sweetpotato.

D. batatas SP-d1, isolated from a diseased sweetpotato root (cv. Juwhangmi) and supplied by the Bioenergy Crop Research Center, National Institute of Crop Science, Rural Development Administration, Muan, Korea in 2015, was used in this study (Lee et al., 2016). Sweetpotatoes (cv. Juwhangmi) obtained from the same center were used in this study. The sweetpotatoes were stored in a moist chamber with $60 \%$ relative humidity $(\mathrm{RH})$ at $15^{\circ} \mathrm{C}$ until use.

To test the in vitro inhibitory effect of gaseous $\mathrm{ClO}_{2}$ against $D$. batatas, $200 \mu 1$ of spore suspensions was spread on acidified potato dextrose agar (APDA) (three plates per treatment as replicate). For inoculum preparation, spores from cultures of isolate SP-d1 grown on potato dextrose agar (PDA) at $25^{\circ} \mathrm{C}$ for 14 days were harvested with $0.03 \%$ Tween 20 and then adjusted to $5 \times 10^{3}$ spores $/ \mathrm{ml}$ using a hemocytometer. The inoculated plates were treated with 1 , 5,10 , and $20 \mathrm{ppm}$ of $\mathrm{ClO}_{2}$ gas for $0,1,10,30$, and $60 \mathrm{~min}$. The gas was generated by a $\mathrm{ClO}_{2}$ generator (PurgoFarm Co. Ltd., Hwasung, Korea) (Supplementary Fig. 1) using an electrochemical method (Gates, 1998). Briefly, aqueous $\mathrm{NaClO}_{2}$ was electrolyzed and the cleaved sodium ions migrated to the cathode through a patented multi-porous membrane electrode assembly, leaving highly pure $\mathrm{ClO}_{2}$ $(>99 \%)$ in the anode chamber. The evaporating $\mathrm{ClO}_{2}$ gas was blown out through a vent into a test chamber [54 (length) $\times 44$ (width) $\times 46$ (height) $\mathrm{cm}$ ]. Gas entry to the chamber was manually controlled depending on the preset concentrations $(1,5,10$, and $20 \mathrm{ppm})$ of $\mathrm{ClO}_{2}$, which were monitored at $0,1,10,30$, and 60 min by a PortaSens II gas leak detector (Analytical Technology, Collegeville, PA, USA) (Supplementary Fig. 1). The $\mathrm{ClO}_{2}$ gas-treated plates were incubated at $25^{\circ} \mathrm{C}$ for 2 days and then colony-forming units (cfus) were determined.

To test the in vivo inhibitory effect of gaseous $\mathrm{ClO}_{2}$ against $D$. batatas via slice test, healthy sweetpotato roots were first washed with tap water and then with distilled water. The clean roots were surface-sterilized by spraying with $70 \%$ ethanol. After drying for $5 \mathrm{~min}$, these roots were rinsed with distilled water twice and then dried for $10 \mathrm{~min}$ at room temperature. Next, the roots were cut into $1-\mathrm{cm}$ thick slices and placed in Petri plates ( $90 \mathrm{~mm}$ in diameter). The centers of these slices (three slices per treatment) were drop-inoculated with $10 \mu \mathrm{l}$ of the spore suspension $\left(5 \times 10^{6}\right.$ spores $/ \mathrm{ml}$ ) harvested as described above. The inoculated slices were then treated with 5,10 , and $20 \mathrm{ppm}$ of $\mathrm{ClO}_{2}$ gas for $0,10,30$, and $60 \mathrm{~min}$ as described above. After $\mathrm{ClO}_{2}$ gas treatment, the slices were put in containers [23 (length) $\times 13$ (width) $\times 16$ (height) $\mathrm{cm}$ ] containing three layers of wet paper towels $(100 \% \mathrm{RH})$ and further incubated at $28^{\circ} \mathrm{C}$. After 10 days of incubation, lesion diameters on the inoculated slices were measured as follows: [longest lesion 
length $(\mathrm{mm})+$ shortest lesion length $(\mathrm{mm})]$ was divided by 2 (Oh et al., 2016). In addition, fungal populations from the lesions on the slices were assessed. Samples from lesions were obtained using a sterile cork borer and were finely ground using an analytical mill (IKA A11 basic, IKA Works, Wilmington, DE) in sterile distilled water (SDW). After appropriate dilutions, samples were spread on APDA, and cfus were counted 2 days after incubation at $25^{\circ} \mathrm{C}$.

To test the in vivo inhibitory effect of gaseous $\mathrm{ClO}_{2}$ against $D$. batatas via the root test, sweetpotato roots were dipped in spore suspensions $\left(5 \times 10^{6}\right.$ spores $\left./ \mathrm{ml}\right)$ or $0.03 \%$ Tween 20 (uninoculated control) for $10 \mathrm{~min}$ (three roots per treatment). The inoculated roots were treated with 20 and $40 \mathrm{ppm}$ of $\mathrm{ClO}_{2}$ gas for 0,30 , and $60 \mathrm{~min}$ as described above. The concentrations of $\mathrm{ClO}_{2}$ gas in this root tests were examined to consider practical applications during postharvest storage. After the $\mathrm{ClO}_{2}$ gas treatment, surface layers of the roots were peeled using a vegetable peeler. Two grams of the samples (approximately $1.5 \mathrm{~mm}$ in thickness) were finely ground using an analytical mill (IKA Works) in $20 \mathrm{ml}$ of SDW. After appropriate dilutions, the samples were spread on APDA. After 2 days of incubation at $25^{\circ} \mathrm{C}$, colonies were counted and expressed as cfu per $\mathrm{g}$ of dry weight.

Experiments were established using factorial designs to observe the effect of $\mathrm{ClO}_{2}$ concentration and treatment time on lesion diameter and fungal population. All experiments were performed twice with three replicates per treatment. In vitro fungal population data from repeated experiments were pooled after confirmation of homogeneity of variances, using Levene's test (Levene, 1960). For analysis of fungal populations, data were analyzed after logarithmic transformation. ANOVA was conducted using general linear model procedures, and the means were separated using least significant difference tests at $P<0.05$. Statistical analysis of the data was conducted using Statistical Analysis Systems software (SAS Institute, Cary, NC, USA).

The inhibitory effect of gaseous $\mathrm{ClO}_{2}$ on $D$. batatas SP-d1 was significant (Fig. 1 and Supplementary Fig. 2). Fungal growth was significantly inhibited at $1 \mathrm{ppm}$ of $\mathrm{ClO}_{2}$ for $1 \mathrm{~min}$ and was almost completely suppressed at $1 \mathrm{ppm}$ for $30 \mathrm{~min}$, as well as at other concentrations of $\mathrm{ClO}_{2}$ treatments, regardless of time (Fig. 1 and Supplementary Fig. 2).

Lesion diameters of $D$. batatas SP-d1 did not change significantly at the concentrations of $\mathrm{ClO}_{2}$ tested; however, lesion diameters decreased with an increase in treatment time in both experiments (Fig. 2, Fig. 3A, and Table 1). The concentration significantly $(P=0.0352)$ affected lesion diameters in one experiment (Table 1). Treatment time significantly $(P=0.0046$ for experiment 1 and $P<0.0001$

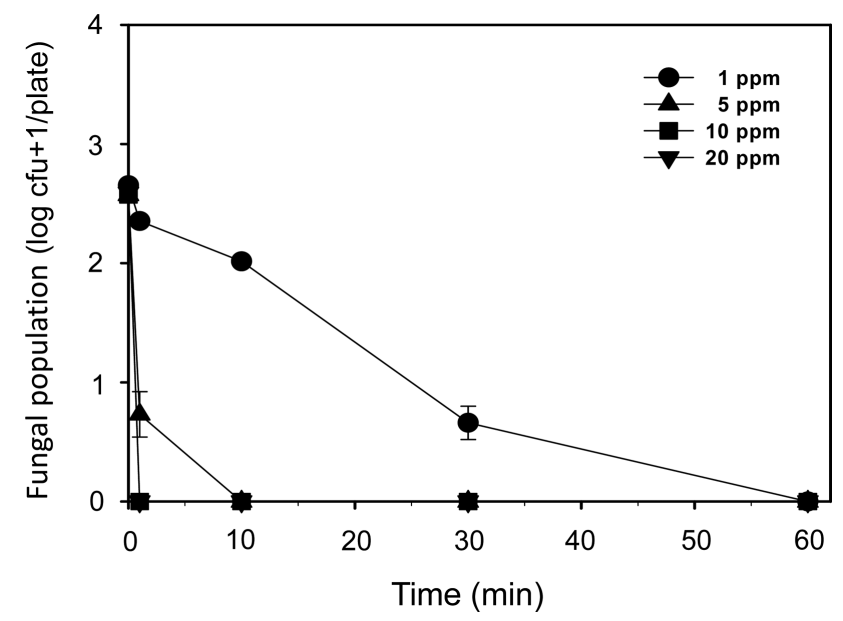

Fig. 1. Populations of Diaporthe batatas SP-d1 on acidified potato dextrose agar treated with various $\mathrm{ClO}_{2}$ concentrations (1, 5,10 , and $20 \mathrm{ppm}$ ) for $0,1,10,30$, and $60 \mathrm{~min}$. Colony-forming units (cfus) were counted 2 days after incubation. Isolate SPd1 $\left(200 \mu \mathrm{l}\right.$ of $5 \times 10^{3}$ spores $\left./ \mathrm{ml}\right)$ was spread on APDA before $\mathrm{ClO}_{2}$ gas treatments. Error bars are the standard deviations of the means $(n=6)$.

for experiment 2) affected lesion diameters on sweetpotato slices in both experiments. Interactions between concentration and time for lesion diameters were not significant $(P>$ 0.05 ) in both experiments (Table 1 ). In addition, the degree of darkness of lesions was reduced over time, regardless of gas concentration, and sweetpotato tissues hardened after gas treatment for $60 \mathrm{~min}$ (Fig. 2). However, disease symptoms were not observed in uninoculated sweetpotato slices (Fig. 2).

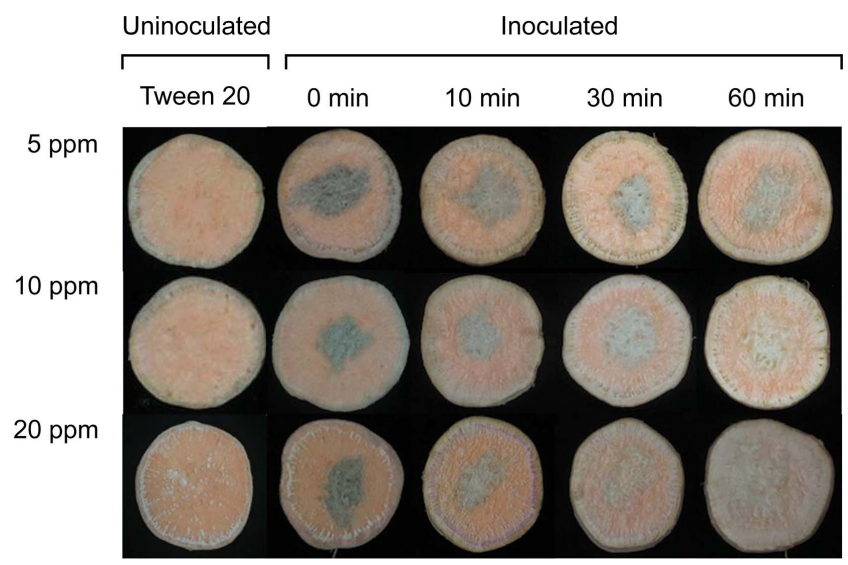

Fig. 2. Photographs of sweetpotato slices drop-inoculated with Diaporthe batatas SP-d1 $\left(10 \mu 1\right.$ of $5 \times 10^{6}$ spores $\left./ \mathrm{ml}\right)$ following treatments with various $\mathrm{ClO}_{2}$ concentrations $(5,10$, and $20 \mathrm{ppm})$ for $0,10,30$, and $60 \mathrm{~min}$. These photographs were taken 10 days after inoculation. 


\section{A Slice test}

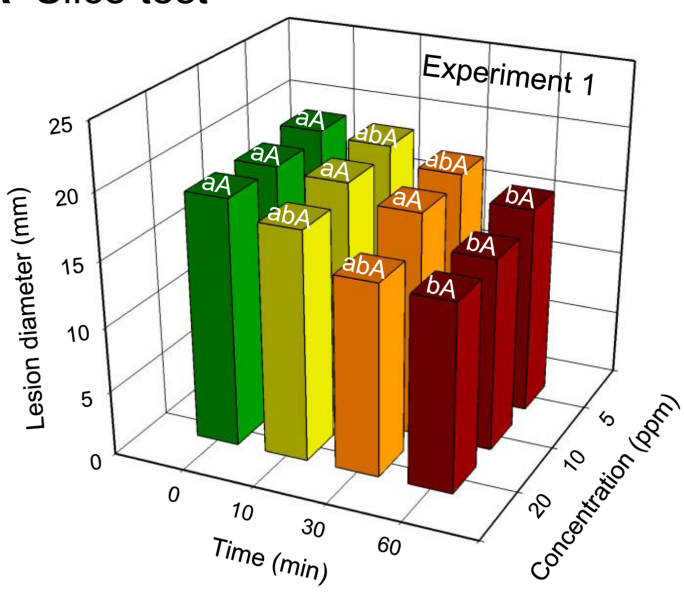

B Slice test

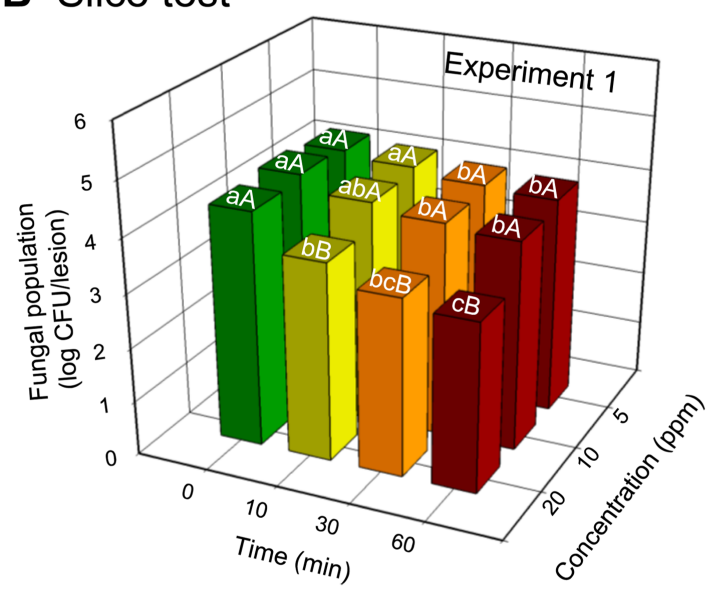

C Root test

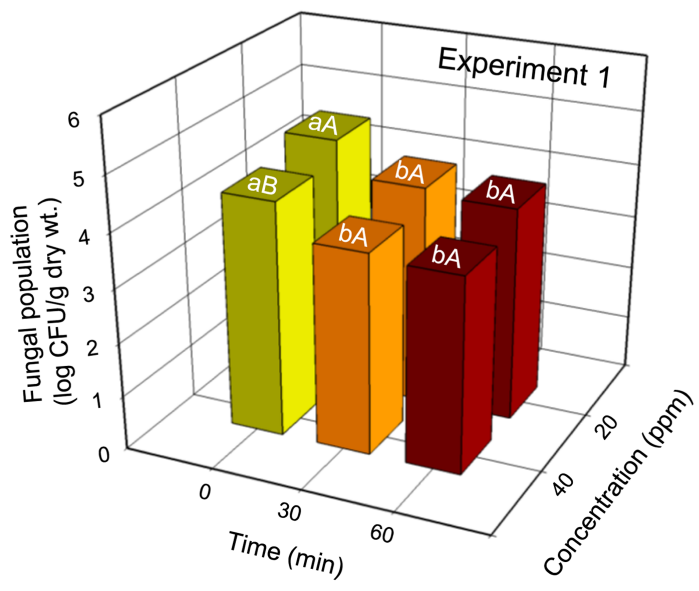

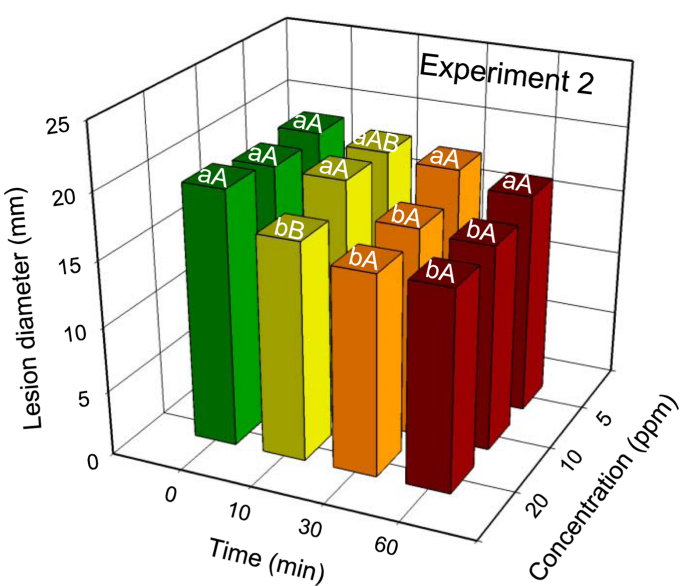
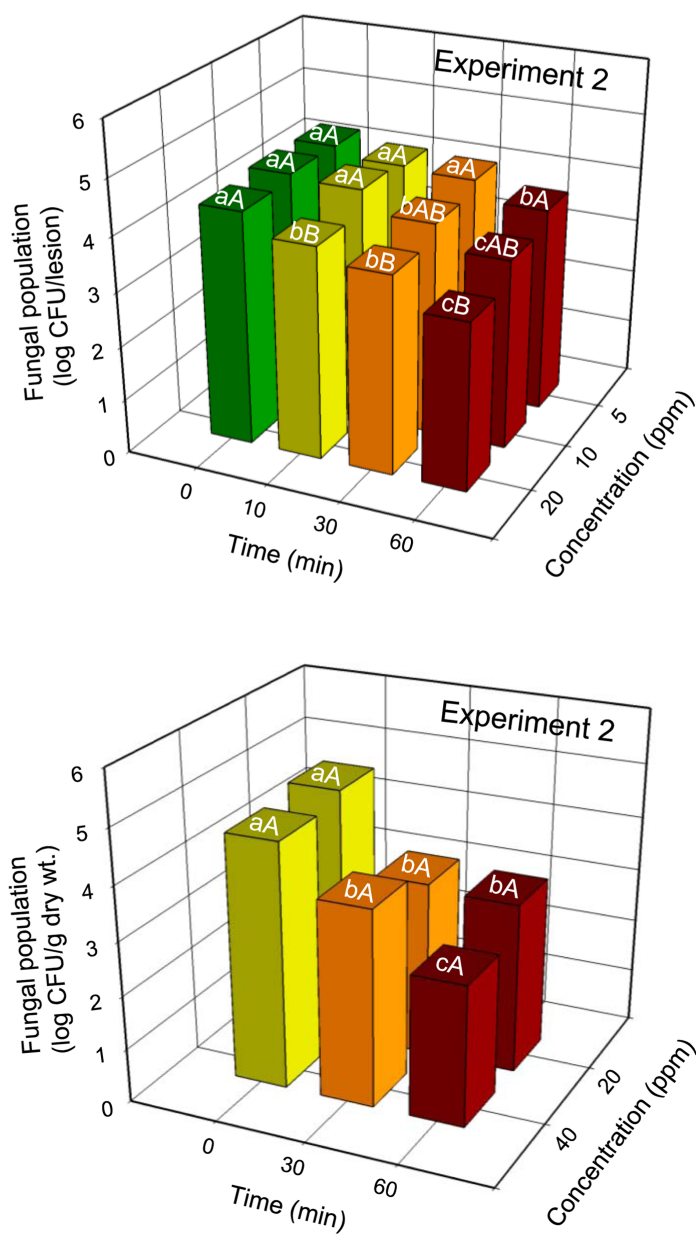

Fig. 3. (A) Lesion diameters and (B) populations of Diaporthe batatas SP-d1 on inoculated slices of sweetpotatoes treated with gaseous chlorine dioxide $\left(\mathrm{ClO}_{2}\right)$. (C) Populations of isolate SP-d1 in the surface layers of sweetpotato roots treated with $\mathrm{ClO}_{2}$ gas. Slices were inoculated with isolate SP-d1 $\left(10 \mu 1\right.$ of $5 \times 10^{6}$ spores $\left./ \mathrm{ml}\right)$ and then treated with various $\mathrm{ClO}_{2}$ concentrations $(5,10$, and $20 \mathrm{ppm})$ for 0,10 , 30 , and $60 \mathrm{~min}$. Roots were dipped in spore suspension $\left(5 \times 10^{6}\right.$ spores $\left./ \mathrm{ml}\right)$ for $10 \mathrm{~min}$ and then treated with different $\mathrm{ClO}_{2}$ concentrations (20 and $40 \mathrm{ppm}$ ) for 0,30, and $60 \mathrm{~min}$. Different lowercase and uppercase letters on bars $(n=3)$ are significantly different between time at a given concentration and between concentrations at a given time according to the least significant difference test at $P<0.05$, respectively. Repeated experiments are indicated as experiments 1 and 2. 
The population of $D$. batatas SP-d1 in the inoculated slices decreased with an increase in $\mathrm{ClO}_{2}$ concentration and treatment time, regardless of experiment (Fig. 3B and Table 1). Fungal inhibition was higher at $20 \mathrm{ppm}$ of $\mathrm{ClO}_{2}$ than 5 ppm, regardless of time, and at 30- and 60-min gas treatments compared with 0 -min gas treatment, regardless of $\mathrm{ClO}_{2}$ concentration in both experiments (Fig. 3B). $\mathrm{ClO}_{2}$ concentrations and treatment times independently resulted in significantly $(P<0.0001)$ reduced fungal growth on sweetpotato slices in both experiments (Table 1). There were significant $(P=0.0073)$ interactions between concentration and time for fungal populations in one experiment (Table 1).

The growth of $D$. batatas SP-d1 did not vary between $\mathrm{ClO}_{2}$ concentrations; however, it decreased with increasing exposure time in both experiments (Fig. $3 \mathrm{C}$ and Table 2). Fungal growth was inhibited at 20 and $40 \mathrm{ppm}$ of $\mathrm{ClO}_{2}$ with the 60 -min gas treatment, compared with the 0 -min gas treatment (Fig. 3C). The concentration of $\mathrm{ClO}_{2}$ resulted in a significant $(P=0.0012)$ reduction in the fungal population in one experiment; the treatment time produced a significant $(P<0.0001)$ reduction in the fungal population in both experiments (Table 2). However, significant interactions between concentration and time for fungal populations were not observed in both experiments (Table 2).

In this study, we tested whether gaseous $\mathrm{ClO}_{2}$ could effectively control infection by $D$. batatas, the causal agent of dry rot on sweetpotato. Consequently, we found that gaseous $\mathrm{ClO}_{2}$ had significant inhibitory activity against the fungal infection on sweetpotato. Furthermore, we detected that treatment time had a greater effect than the concentration of $\mathrm{ClO}_{2}$ gas on the growth of D. batatas SP-d1 and dry rot development in the crop.

In the in vitro test, growth of $D$. batatas SP-d1 was partially inhibited at $1 \mathrm{ppm} \mathrm{ClO}_{2}$ treatment for $30 \mathrm{~min}$. With the 10-and 20-ppm $\mathrm{ClO}_{2}$ treatments, the tested fungus was completely inhibited. Similarly, there have been several studies that demonstrated the in vitro inhibitory efficiency of $\mathrm{ClO}_{2}$ on fungal pathogens. For example, the radial growth of Alternaria alternata and Stemphylium vesicarium were completely inhibited after a 3 min treatment with 10 ppm of $\mathrm{ClO}_{2}$ gas (Trinetta et al., 2013). In other

Table 1. Analysis of variance components including the degrees of freedom (df), sum of squares (SS), $F$ ratio, and $P$ value for lesion diameters and fungal populations of Diaporthe batatas SP-d1 on inoculated slices of sweetpotatoes treated with gaseous chlorine dioxide $\left(\mathrm{ClO}_{2}\right)$

\begin{tabular}{|c|c|c|c|c|c|c|c|c|c|c|c|c|c|c|c|c|}
\hline \multirow{3}{*}{ Source of variation } & \multicolumn{8}{|c|}{ Lesion diameter $(\mathrm{mm})^{\mathrm{a}}$} & \multicolumn{8}{|c|}{ Fungal population (log cfu/lesion) ${ }^{\mathrm{a}}$} \\
\hline & \multicolumn{4}{|c|}{ Experiment 1} & \multicolumn{4}{|c|}{ Experiment 2} & \multicolumn{4}{|c|}{ Experiment 1} & \multicolumn{4}{|c|}{ Experiment 2} \\
\hline & df & $S S$ & $F$ & $P$ & df & $S S$ & $F$ & $P$ & df & $S S$ & $F$ & $P$ & $\mathrm{df}$ & $S S$ & $F$ & $P$ \\
\hline Concentration & 2 & 16.0 & 1.5 & 0.2460 & 2 & 12.2 & 3.9 & 0.0352 & 2 & 2.2 & 32.3 & $<0.0001$ & 2 & 0.9 & 15.6 & $<0.0001$ \\
\hline Time & 3 & 90.9 & 5.6 & 0.0046 & 3 & 58.0 & 12.3 & $<0.0001$ & 3 & 2.4 & 23.9 & $<0.0001$ & 3 & 3.9 & 43.5 & $<0.0001$ \\
\hline $\begin{array}{l}\text { Concentration } \times \\
\text { time }\end{array}$ & 6 & 7.2 & 0.2 & 0.9653 & 6 & 11.2 & 1.2 & 0.3495 & 6 & 0.8 & 3.9 & 0.0073 & 6 & 0.4 & 2.2 & 0.0843 \\
\hline
\end{tabular}

${ }^{a}$ Sweetpotato slices were drop-inoculated with isolate SP-d1 $\left(10 \mu 1\right.$ of $5 \times 10^{6}$ spores $\left./ \mathrm{ml}\right)$ and then treated with various $\mathrm{ClO}_{2}$ concentrations $(5$, 10 , and $20 \mathrm{ppm}$ ) for $0,10,30$, and $60 \mathrm{~min}$. Lesion diameters and colony-forming units (cfus) were evaluated 10 days after incubation at $28^{\circ} \mathrm{C}$. Repeated experiments are indicated as experiments 1 and 2.

Table 2. Analysis of variance components including the degrees of freedom (df), sum of squares ( $S S$ ), $F$ ratio, and $P$ value for fungal populations of Diaporthe batatas SP-d1 in surface layers of sweetpotato roots treated with gaseous chlorine dioxide $\left(\mathrm{ClO}_{2}\right)$

\begin{tabular}{|c|c|c|c|c|c|c|c|c|}
\hline \multirow{3}{*}{ Source of variation } & \multicolumn{8}{|c|}{ Fungal population (log cfu/g dry wt. $)^{\mathrm{a}}$} \\
\hline & \multicolumn{4}{|c|}{ Experiment 1} & \multicolumn{4}{|c|}{ Experiment 2} \\
\hline & df & $S S$ & $F$ & $P$ & $\mathrm{df}$ & $S S$ & $F$ & $P$ \\
\hline Concentration & 1 & 0.6 & 17.8 & 0.0012 & 1 & 0.1 & 0.4 & 0.5614 \\
\hline Time & 2 & 1.8 & 29.2 & $<0.0001$ & 2 & 9.6 & 30.3 & $<0.0001$ \\
\hline Concentration $\times$ time & 2 & 0.0 & 0.0 & 0.9971 & 2 & 0.7 & 2.2 & 0.1584 \\
\hline
\end{tabular}

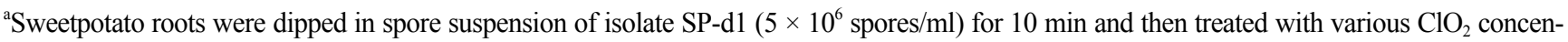
trations (20 and $40 \mathrm{ppm}$ ) for 0,30 , and $60 \mathrm{~min}$. After $\mathrm{ClO}_{2}$ gas treatment, colony-forming units (cfus) on the surface layers of the roots were determined. Repeated experiments are indicated as experiments 1 and 2. 
studies, the impact of atmospheric chlorine on spore viability and mycelial growth of Botrytis cinerea and Rhizopus stolonifer were evaluated (Avis et al., 2006). A chlorine concentration of $10 \mathrm{ppm}$ was sufficient to inhibit fungal spore germination, while mycelial growth of the fungi was completely inhibited at concentrations of 5 and $20 \mathrm{ppm}$ at 6 $\mathrm{h}$ after treatment (Avis et al., 2006).

In the in vivo tests, $\mathrm{ClO}_{2}$ gas consistently restricted lesion diameters for the 60-min treatment, but not for the 10- and 30 -min treatments, at concentrations of 10 and $20 \mathrm{ppm}$ in repeated experiments. However, lesion color (indicating fungal growth) on the slices changed over time, and the tissues hardened after gas treatment for $60 \mathrm{~min}$, especially at $20 \mathrm{ppm}$ of $\mathrm{ClO}_{2}$. Therefore, the fungal populations of infected tissues were evaluated for a more accurate assessment of inhibitory activity of $\mathrm{ClO}_{2}$ gas. Populations of $D$. batatas SP-d1 greatly decreased at the tested $\mathrm{ClO}_{2}$ concentrations over time, especially at $20 \mathrm{ppm}$ of $\mathrm{ClO}_{2}$ for $30-60$ $\mathrm{min}$. However, considering tissue hardening after $60 \mathrm{~min}$ of $\mathrm{ClO}_{2}$ treatment, a 30-min treatment may be appropriate. On the other hand, the root dip tests for fungal populations also showed similar results compared with the slice tests as observed in other studies (Jin-Hua et al., 2007; Lee et al., 2004). For example, when green bell peppers were treated with $0-50 \mathrm{ppm}$ of $\mathrm{ClO}_{2}$ gas at $10 \pm 0.5^{\circ} \mathrm{C}$ for 40 days, pepper rot was inhibited at all of the tested $\mathrm{ClO}_{2}$ gas concentrations (Jin-Hua et al., 2007). Similarly, reductions in Escherichia coli, Salmonella typhimurium, and Listeria monocytogenes were observed when inoculated lettuce was exposed to $\mathrm{ClO}_{2}$ gas for 0.5-3 h (Lee et al., 2004).

Taken together, our results in this study showed that gaseous $\mathrm{ClO}_{2}$ could significantly inhibit $D$. batatas growth and dry rot development on sweetpotato. In particular, $20 \mathrm{ppm}$ of $\mathrm{ClO}_{2}$ gas treatment for $30 \mathrm{~min}$ may be appropriate to inhibit fungal growth and disease development on the crop. Hence, gaseous $\mathrm{ClO}_{2}$ could be used to control this fungal disease during the postharvest storage of sweetpotato roots.

\section{Acknowledgments}

This work was supported by a grant from the Rural Development Administration (PJ011332) in Korea. J.-J. Jeong was supported by the Global Ph.D. program through the National Research Foundation of Korea funded by the Ministry of Education (2015-034526) in Korea.

\section{References}

Afek, U., Orenstein, J. and Nuriel, E. 1998. Increased quality and prolonged storage of sweet potatoes in Israel. Phytoparasitica
26:307-312.

Amienyo, C. A. and Ataga, A. E. 2007. Use of indigenous plant extracts for the protection of mechanically injured sweet potato [Ipomoea batatas (L.) Lam] tubers. Sci. Res. Essays 2:167-170.

Avis, T. J., Martinez, C. and Tweddell, R. J. 2006. Effect of chlorine atmospheres on the development of Rhizopus rot (Rhizopus stolonifer) and gray mold (Botrytis cinerea) on stored strawberry fruits. Can. J. Plant. Pathol. 28:526-532.

Chakraborty, C., Roychowdhury, R., Chakraborty, S., Chakravorty, P. and Ghosh, D. 2017. A review on post-harvest profile of sweet potato. Int. J. Curr. Microbiol. App. Sci. 6:1894-1903.

Du, J., Han, Y. and Linton, R. H. 2002. Inactivation by chlorine dioxide gas $\left(\mathrm{ClO}_{2}\right)$ of Listeria monocytogenes spotted onto different apple surfaces. Food Microbiol. 19:481-490.

Gates, D. J. 1998. The chlorine dioxide handbook, American Water Works Association, Denver, CO, USA.

Han, Y., Linton, R. H., Nielsen, S. S. and Nelson, P. E. 2001. Reduction of Listeria monocytogenes on green peppers (Capsicum annuum L.) by gaseous and aqueous chlorine dioxide and water washing and its growth at $7^{\circ} \mathrm{C}$. J. Food Prot. 64:1730-1738.

Han, Y., Selby, T. L., Schultze, K. K., Nelson, P. E. and Linton, R. H. 2004. Decontamination of strawberries using batch and continuous chlorine dioxide gas treatments. J. Food Prot. 67:2450-2455.

Harter, L. L. and Field, E. C. 1912. Diaporthe, the ascogenous form of sweet potato dry rot. Phytopathology 2:121-124.

Jin-Hua, D. U., Mao-Run, F. U., Miao-Miao, L. I. and Wei, X. I. A. 2007. Effects of chlorine dioxide gas on postharvest physiology and storage quality of green bell pepper (Capsicum frutescens L. var. Longrum). Agr. Sci. China 6:214-219.

Lee, S. Y., Costello, M. and Kang, D. H. 2004. Efficacy of chlorine dioxide gas as a sanitizer of lettuce leaves. J. Food Prot. 67:1371-1376.

Lee, Y. J., Mannaa, M., Jeong, J. J., Lee, H. U., Kim, W. and Kim, K. D. 2016. First report of dry rot of sweetpotato (Ipomoea batatas) caused by Diaporthe batatas in Korea. Plant Dis. 100:1786.

Levene, H. 1960. Robust tests for equality of variances. In Contributions to Probability and Statistics, eds. by I. Olkin, S.G. Ghurye, W. Hoeffding, W.G. Madow and H.B. Mann, pp. 278-292. Stanford Univ. Press, Stanford, CA, USA.

Mannaa, M. and Kim, K. D. 2018. Biocontrol activity of volatileproducing Bacillus megaterium and Pseudomonas protegens against Aspergillus and Penicillium spp. predominant in stored rice grains: study II. Mycobiology 46:52-63.

Oh, J. Y., Mannaa, M. Han, G. D., Chun, S.-C. and Kim, K. D. 2016. First report of Aspergillus awamori as a fungal pathogen of garlic (Allium sativum L.). Crop Prot. 85:65-70.

Ray, R. C. and Ravi, V. 2005. Post-harvest spoilage of sweet potato in tropics and control measures. Crit. Rev. Food Sci. Nutr. 45:634-644.

Sanusi, M. M., Lawal, O. I., Sanusi, R. A. and Adesogan, A. 
O. 2016. Profitability of sweet potato production in derived savannah zone of Ogun State, Nigeria. J. Agric. Soc. Res. 16:16-27.

Scruggs, A. C. and Quesada-Ocampo, L. M. 2016. Etiology and epidemiological conditions promoting Fusarium root rot in sweetpotato. Phytopathology 106:909-919.

Singh, D. and Sharma, R. R. 2018. Postharvest diseases of fruits and vegetables and their management. Ed. M. W. Siddiqui, In: Postharvest Disinfection of Fruits and Vegetables. Pp. 1-52. Academic Press.

Sy, K. V., McWatters, K. H. and Beuchat, L. R. 2005a. Efficacy of gaseous chlorine dioxide as a sanitizer for killing Salmonella, yeasts, and molds on blueberries, strawberries, and raspberries. J. Food Prot. 68:1165-1175.

Sy, K. V., Murray, M. B., Harrison, M. D. and Beuchat, L. R. 2005b. Evaluation of gaseous chlorine dioxide as a sanitizer for killing Salmonella, Escherichia coli O157:H7, Listeria monocytogenes, yeasts, and molds on fresh and fresh-cut produce. J. Food Prot. 68:1176-1187.

Trinetta, V., Linton, R. H. and Morgan, M. T. 2013. Use of chlorine dioxide gas for the postharvest control of Alternaria alternata and Stemphylium vesicarium on Roma tomatoes. J. Sci. Food Agric. 93:3330-3333.

Tweddell, R. J., Boulanger, R. and Arul, J. 2003. Effect of chlo- rine atmospheres on sprouting and development of dry rot, soft rot and silver scurf on potato tubers. Postharvest Biol. Technol. 28:445-454.

U.S. Environmental Protection Agency. 2006. Pesticides - Reregistration eligibility decision (RED) for chlorine dioxide and sodium chlorite (Case 4023). URL https://www3.epa.gov/ pesticides/chem_search/reg_actions/reregistration/red_PC020503_3-Aug-06.pdf [16 August 2018].

Vaid, R., Linton, R. H. and Morgan, M. T. 2010. Comparison of inactivation of Listeria monocytogenes within a biofilm matrix using chlorine dioxide gas, aqueous chlorine dioxide and sodium hypochlorite treatments. Food Microbiol. 27:979984.

Wang, T., Qi, J., Wu, J., Hao, L., Yi, Y., Lin, S. and Zhang, Z. 2016. Response surface modeling for the inactivation of $B a$ cillus subtilis subsp. niger spores by chlorine dioxide gas in an enclosed space. J. Air Waste Manage. Assoc. 66:508-517.

Wu, V. C. and Rioux, A. 2010. A simple instrument-free gaseous chlorine dioxide method for microbial decontamination of potatoes during storage. Food Microbiol. 27:179-184.

Zoffoli, J. P., Latorre, B. A., Rodriguez, E. J. and Aldunce, P. 1999. Modified atmosphere packaging using chlorine gas generators to prevent Botrytis cinerea on table grapes. Postharvest Biol. Technol. 15:135-142. 